This is the peer reviewed version of the following article Dow, S. C. and Smithin, J. (1999), The Structure of Financial Markets and the 'First Principles' of Monetary Economics. Scottish Journal of Political Economy, 46: 72-90, which has been published in final form at https://doi.org/10.1111/1467-9485.00121. This article may be used for non-commercial purposes in accordance with Wiley Terms and Conditions for Self-Archiving. 
Pre-publication version of the article published in the Scottish Journal of Political Economy, 46(1):72-90, February 1999.

\title{
The Structure of Financial Markets and the 'First Principles' of Monetary Economics
}

\author{
by
}

\section{Sheila C. Dow and John Smithin}

The authors would like to thank Kevin Dowd, John Foster, Ingrid Rima, T.K. Rymes, George Selgin, and Hans-Michael Trautwein, who have all made valuable comments either on earlier drafts of the present paper or on related work in the same research programme.

* Dept. of Economics, University of Stirling, Stirling FK9 4LA, Scotland.

* * Dept. of Economics and FAS, York University, North York, Ontario M3J 1P3, Canada . 


\section{ABSTRACT \\ Change in Financial Markets and the First Principles of Monetary Economics}

\section{Sheila C Dow and John Smithin}

There has been a significant degree of financial restructuring over the last few decades, which has prompted a rethinking of the first principles of monetary economics. The focus here is on how four specifications of these principles address the question of the desirability of central banks. The case is made for one approach, which advocates central banking as being integral to the logic of credit relations, which in turn are at the heart of monetary systems. It is argued that monetary history demonstrates that monetary standards and central banking have indeed tended to be the outcome of competition in the financial sector.

\section{Key words:}

Monetary theory

Central bank

Monetary history 
In the past several years a substantial literature has arisen discussing the merits of laissez-faire in the financial services industry and the provision of payments systems. Several comprehensive surveys are available, as in Cowen and Kroszner (1994), Dowd (1993), Selgin and White (1994) and, from a more critical perspective, Smithin (1994) and Trautwein (1993). A number of convergent influences seem to have been responsible for the re-emergence of this debate in the current era. These would include, first, a straightforward extension to the monetary arena of the increasingly popular case for laissez-faire in other areas (Dowd, forthcoming). Second, the rapid pace of technical change, including the computerisation of banking systems and financial markets, seems finally to make possible the substitution of 'sophisticated accounting systems of exchange' (McCallum, 1985) for conventional monetary systems. For the first time, the Walrasian barter-exchange economy is apparently a potential reality rather than a convenient theoretical abstraction (Smithin, 1994). Finally, theory has developed in response to perceptions of poor performance of existing centralbank-dominated systems (Buchanan and Fand, 1993).

One key question which has been widely debated is whether, in some hypothetical deregulated and financially-innovated system, there would be any need for an institution analogous to a central bank, which would be capable of conducting monetary policy. Many authors, particularly in the new monetary economics (NME) and modern free banking (MFB) traditions, think not. Another important issue which has received attention is the feasibility and desirability of separating the traditional functions of money, such as medium of exchange and unit of account. A number of scenarios has been put forward in which a radical separation of the monetary functions is both feasible and economically efficient.

This paper puts forward arguments against both of these positions, on the basis of a different monetary-theoretic foundation. According to this alternative perspective, money is essential to the economic process, and 'moneyness' has some of the characteristics of a public good. The practical operation of production and exchange in capitalist economies requires that there be a basic monetary asset which unamibiguously represents the standard of value and is universally acceptable 
in the ultimate discharge of debts. The role of this asset is to mitigate the actual or potential fundamental uncertainty which, as Keynes and certain Post Keynesians have argued, pervades the economic environment. If such an asset exists, it provides a public service in the sense that it enables the system of market exchange to develop. It is a precondition for the system in the same way that there must also be a legal apparatus to enforce contracts.

The fulfilment of these conditions requires that at least the functions of the unit of account and medium of settlement be united in the same asset, even if there is a multiplicity of media of exchange. This view is shared by the MFB school, though based on transactions costs arguments rather than uncertainty. However, according to Selgin and White (1994), the base money regime is not uniquely specified by free banking. This is an important omission, because, where the liabilities of a trustworthy financial institution (rather than, say, gold) act as the base money, that institution can then mitigate a Minsky-type crisis (Minsky, 1978, 1986) via Bagehot's $(1873,1915)$ expedient of continued lending at some appropriate interest rate. In other words, the money supply can be made fully endogenous.

Against the public good argument for public sector provision of base money, it has been pointed out that private provision of the necessary monetary services can evolve spontaneously via processes analogous to those analysed by Menger (1892). But it has not been satisfactorily demonstrated that the outcome would be the perfectly competitive system envisaged by advocates of laissez-faire. Contrary to Dowd (forthcoming), it is not necessary for our argument to confine attention to the alternative extreme of a single central bank-like institution. It is quite feasible to imagine a number of rival financial networks operating side-by-side, just as there are currently dollar, yen and DM networks today. Natural monopoly problems are however inherent in the development of trustworthy credit relations in an environment subject to irreducible uncertainty, if not in the money production process itself, which preclude the perfectly competititve solution. The appropriate market form would be monopolistic competition rather than perfect competititon. Public policy issues then arise concerning the degree of power that is in private rather than public hands. Ironically, the various laissez-faire proposals of recent years, if strictly enforced (itself an 
interference with the natural course of events), would actually prevent the emergence of assets with the appropriate degree of moneyness and endogeneity.

These arguments are developed more fully below. Section I distinguishes between the monetary-theoretic foundations underlying different approaches to financial regulation; Section II develops the implications of a credit-based system approach; Section III considers the likely effects of deregulation on the structure of the financial sector; Section IV develops the public good and natural monopoly argument against laissez-faire; Section $\mathrm{V}$ analyses the evidence on laissez-faire banking systems.

\section{ALTERNATIVE THEORIES OF MONEY}

Broadly speaking, at least four alternative theoretical perspectives can be identified. The first is the NME school, which has gone furthest in presenting the view that money as such may be dispensible. Among the most widely-cited contributors are Black (1970), Cowen and Kroszner (1987, 1994), Fama (1980, 1983), Hall (1982a, 1982b), and Greenfield and Yeager (1983, 1989). A distinction is sometimes made between work in this tradition and that

of the so-called 'legal restrictions' theorists (LRT), whose leading figure is Wallace (1983, 1988). More commonly, however, the similarities betweeen the two groups are stressed, as in Cowen and Kroszner (1989). The overall approach seems to be motivated on the one hand by a longstanding commitment to a vision of an economic system operating along Walrasian lines, and, on the other, by the idea that contemporary technological and institutional changes are finally making conventional monetary exchange obsolete. The latter considerations may explain why this viewpoint became prominent in the 1980s during a period of fairly rapid technological, institutional and regulatory innovation.

Although each of the authors cited has put forward his own distinctive point of view, the commmon theme is the feasibility of one version or another of a completely deregulated competitive payments system which is 'cashless' in the sense of lacking an outside or base money, and in which there is, or may be, separation of monetary functions (Cowen and Kroszner, 1994). In some popular 
scenarios, the unit of account is defined in terms of some composite commodity bundle, chosen such that prices quoted in it can be expected to be relatively stable. The unit of account plays a role in the financial world analogous to weights and measures, rather than that of a reserve asset into which promises-to-pay are ultimately redeemable. The only role of government in the system would be to define this unit of account and possibly conduct its own transactions in these terms. The exchange media themselves need not be restricted to the fixed-nominal-value deposit liabilities of institutions similar to banks but could also include, for example, transferable claims to shares of an equity-based portfolio analogous to money-market mutual funds. There would be numerous competing media-of-exchange whose value in terms of the unit of account may vary with market conditions. There would be no well defined concept of the money supply, all the potential exchange media would pay competitively determined yields, and the pre-conditions for the conduct of conventional monetary policy would not exist.

It is recognized, as in Greenfield and Yeager (1989), that for claims against diverse financial institutions to be acceptable, there must exist some general medium of redemption (sometimes called the medium of settlement) whereby promises to pay may ultimately be discharged. This is not, however, the composite commodity defining the unit of account, due to the assumed inconvenience of transporting and storing the commodities involved. The redemption medium is rather some more generally acceptable asset which itself varies in unit of account value. It is argued that price level stability is then assured by a system of 'indirect convertibility' (Greenfield and Yeager, 1989), even though there are a number of technical problems involved in the conceptualisation of such a system, as discussed by Selgin and White (1994).

The adherents of NME have put forward scenarios which have been variously described as 'theories of finance without money' (Trautwein, 1993) or 'sophisticated barter system(s)' (Fama, 1980, Cowen and Kroszner, 1987) in which the characteristic problems of a monetary economy do not arise; technological advances are seen as making the Walrasian vision of the economy a practical possibility.

The second major approach to monetary issues, which might be dubbed the 'implicit 
mainstream view' would presumably persevere with the notion of money as some set of perfectlysubstitutable assets, collectively comprising a uniquely acceptable medium of exchange, even if the forms which this medium might take are altered by technological and other changes, and statistical definition becomes increasingly difficult. This second view is only implicit in mainstream economics, however, because most formal monetary models have been notoriously unable to capture this feature adequately, and have concentrated primarily on money as a store of value. It has been pointed out by a number of authors, including Hahn (1983), Hoover (1988), Rogers (1989) and Laidler (1990a,b), that models based explicitly or implicitly on Walrasian microfoundations have no real role for money to play, and that the various devices employed to incorporate monetary elements into such models (cash in advance, money in the utility function, overlapping generations, etc.) have only succeeded in doing so in a superficial fashion'. This is why the textbook account of money, as simply an essential lubricant of economic activity which eliminates the inefficiencies of barter, has not been made operational in any of the conventional monetary models currently in use. The Walrasian auctioneer provides a (fictitious) method of coordinating activities in a market economy without the need for monetary exchange. Hence, it is not surprising that models which easily solve problems of information and coordination via the auctioneer can find no role for money.

Laidler (1990a) argues forcefully (albeit with reference to new-classical economics rather than NME) that it is a mistake to base monetary theory on Walrasian foundations, because monetary exchange is the real world substitute for Walrasian markets which are non-existent in practice. Although Laidler makes explicit reference only to the new-classical approach, his analysis applies equally to the NME-LRT literature, whose underlying model of the economy, though less formally-expressed, is very similar.

A third basic view of the monetary economy, which has some features in common with NME, but also some crucial differences, is represented by the contemporary revival of interest in free banking (Dowd, 1993). Members of the MFB school attribute most contemporary monetary problems directly to government interference in the financial marketplace, either by regulation, deposit insurance or the establishment of state-run central banks; they make corresponding claims 
for the superiority of a laissez-faire system. A selective sampling of the literature would include contributions by Dowd (1989, 1993), Glasner (1989), Sechrest (1993), Selgin (1988) and White (1984a, 1989).

As in the case of the NME-LRT school, each author has his own individual approach. But they are united by the influence of the Austrian approach to economics, inspiration being drawn from authors such as Hayek $(1976 ; 1978)$ and Smith $(1936 ; 1990)$. To that extent, they therefore take a different view of the role of money from the MFB and NME-LRT group, even while sharing with the latter a preference for laissez-faire in the financial services industry. Some for example adopt the early-Austrian emphasis on the medium-of-exchange function in facilitating the transactions process (see for example White, 1984b, 1987, and Selgin and White,1987), in contrast to the Walrasian basis of NME-LRT theory.

Menger's(1892) monetary theory is adopted to explain the convergence of a market system on a common monetary standard purely in terms of the self-interest of traders in the system, and without the need to invoke any form of legal restrictions. An 'invisible hand' argument is used to suggest that the traders' interest in reducing transactions costs will prompt eventual convergence on a single commodity as the standard. (In modern conditions, this could alternatively be a single financial asset.) This is the commodity which will be the most generally acceptable or 'saleable' to others, a property which is self-reinforcing once a particular choice begins to emerge.

Transaction costs arguments, and the historical record, are used to suggest that the unit of account function is likely to be inextricably bound up with that of the medium of exchange (White, 1984a). In fact, however, the argument can be applied more defensibly to the identity of the unit of account with the final medium of settlement (Selgin and White, 1994). It is believed to be unlikely that the separation of these two functions (as suggested in the NME literature) would occur spontaneously due to efforts to minimize calculation and negotiation costs. On this view, the separation of the unit of account and medium of exchange functions could not occur (and be maintained) except by legislative intervention.

The distinctive monetary-theoretic foundations of the MFB approach, as opposed to the 
NME-LRT approach, have led to the conclusion that functioning market economies do require some ultimate repository of purchasing power. Once this point is established, however, it would seem that issues of centralization, power and control must inevitably arise. These problems, however, tend to be elided in most discussions of free banking ${ }^{2}$.

The fourth and final approach to be considered focuses on the relationship between money and credit in an environment subject to uncertainty, and in which promises-to-pay are therefore inevitably of differing quality. We can identify this approach primarily with the Post Keynesian economists, such as Davidson (1978), Kaldor (1970, 1986), Lavoie (1984), Moore (1988) and Shackle (e.g. 1974) and also in the later work of Hicks $(1967,1982,1989)^{3}$. The basic argument is that the origins of money lie not so much in the need to eliminate the inefficiency of barter in a static exchange economy, but in the requirement to develop trustworthy credit relations in the real world market economy in which both production for sale in the market and most exchange relations have a temporal dimension. Money, in other words, is intimately involved with issues of credit, speculation and non-quantifiable risk (Trautwein, 1993). On this view, the evolution of the monetary system, including recent developments, is best understood by starting with credit relations.

\section{MONEY AND CREDIT}

In his last book, Hicks (1989), has gone furthest in locating the microfoundations of monetary economics very firmly in the relationship between money and credit. The argument is that all monetary relations which go beyond the unrealistic case of simultaneous barter have a basic credit element, and that the evolutionary aspect of monetary systems (also stressed by such authors as Chick, 1986, and Moore, 1988) is best understood if credit is the starting point.

As Hicks explained it, in any but the most simple economy the representative transaction is not a simple 'spot' payment of goods for goods (under barter) or money for goods (under monetary exchange), but usually involves either advance or deferred payment in some way. There are three temporally separated stages: making a contract or bargain, delivery of goods or services, and delivery of means-of-payment. The only timing rule is that the contractual agreement comes first; in some cases the means of payment will be delivered before the goods and services (cash in advance), in 
others final payment comes after the delivery of goods and services (as in consumer or trade credit). The key point is that, as soon as the temporal element is introduced, the issue inevitably arises of uncertainty as to whether the terms of the contract can or will be fulfilled. The evolution of money/credit systems is a means of mitigating or reducing these concerns. In such a system, two debts are created immediately after the initial contract is made: one in terms of 'money', the other in 'real' goods and services. The role of money is twofold. It plays a part in fixing the terms of the original contract, and it is also the means by which the debt is settled. In the first role, it is performing the medium of account and unit of account functions of the textbooks. Hicks sums this up as the standard of value. In its second role money is literally a means of pavment. The store of value aspect of money is of less importance because there will usually be other stores of value, possibly with better rates of return, which do not perform monetary functions.

The argument has even more force in the context of the financing of production than in the case of simple exchange transactions (Wray, 1990). On the issue of the possible separation of the monetary functions we can pursue the Hicksian line of reasoning by observing that if the object of the exercise is the fixing of debt contracts in terms of 'money', and their ultimate settlement, there must be some agreement on both sides as to what would unambiguously constitute final payment. It is implicit, therefore, that the asset serving as the standard of value (or rather units of which serve as the standard of value) should itself be acceptable as final payment, that is as the medium of redemption or settlement. In this sense the functions are inseparable.

However, as in the various alternative scenarios discussed above, the standard monetary asset need not be the only actual medium of exchange. It is clearly open to parties to any individual transaction to regard debts as settled among themselves via the transfer of some other asset which is not itself the standard of value, but is nonetheless regarded as equivalent to the requisite number of units of the standard. For example, a debt owed by party A to party B might be offset by a preexisting debt from party $\mathrm{C}$ to A now transferred to $\mathrm{B}$ for final collection. Any number of such chains of interlocking claims is possible, provided only that they are acceptable to the parties concerned (in this case provided that $\mathrm{B}$ has confidence that the debt from $\mathrm{C}$ will really be paid). Hence, there could be a large number of alternative assets or 'promises to pay' which serve as actual media of 
exchange but do not themselves possess the twin properties of defining the standard of value and representing ultimate payment. The difference between this system and the sophisticated barter system is that, to command confidence, the alternate exchange media must all be related to the ultimate standard in some way, typically as credible promises to pay units of the standard asset. It will always be feasible for some players in the system, by mutual agreement, to continue to engage in barter-type exchange involving assets whose prices fluctuate in unit of account value. Even with dramatic improvements in pricing technology, however, such trades will continue both to impose additional negotiation costs and increase uncertainty from the point of view of the recipient, who must make a forecast of the future market value of the assets received. Hence, it is difficult to envisage barter-type trades as a generalised rather than a localised system.

The case where many of the exchange media do represent promises to pay sums of the standard monetary asset leads directly on to a recognition of the basic problems which have traditionally characterised the money/credit economy. The system can be reasonably elastic and expansive when confidence in the alternate exchange media is high, as these claims will then be accepted on face value and can circulate widely for long periods without actually being presented for payment. However, when for some reason confidence evaporates, the system will suddenly appear to be much less stable. The alternate exchange media will no longer be quite so acceptable. At some point, confidence in them may disappear altogether and the traditional financial crisis will develop in which there will be a scramble for redemption of promises to pay in terms of the asset which is regarded as representing ultimate payment.

It is the standard asset, variously described in the literature as the medium of redemption, base money, or, simply, as 'cash' in which the twin monetary functions of the standard of value and means of payment will be intertwined. In contrast, the total of alternate monetary claims which are acceptable for the time being is what is usually described as the 'monetary aggregates' or the 'money supply'. It is easy to see why in times of rapid financial innovation this latter total becomes very difficult to define statistically.

If it is once accepted that a credit-based system does logically need to generate a unique ultimate means of payment and standard of value, it then becomes clear that the issuer of such 
claims, whether or not this is a government institution, will occupy a powerful place in the centre of the financial system. In other words, the requirements of a credit-based system may explain the apparently inexorable tendency towards the centralisation and concentration of financial power in the market economy.

\section{CENTRALISING TENDENCIES IN MONETARY SYSTEMS}

Many economists seem to believe that the high degree of centralisation actually observed in real world monetary and financial systems is simply an artifact of government regulation. If this were removed, the argument seems to be, there would be nothing to stand in the way of the development of a competitive and efficient financial system, free of power relations, which would allow the real economy to approximate as closely as possible the idealised Walrasian barter system. Certainly, most existing central banks developed either out of a historical process in which governmental privileges were granted to some favoured private institution, or directly as result of legislation.

However, if money is seen as evolving primarily from credit relations, in which questions of trust and confidence are paramount, there would seem to be powerful forces pushing the system towards concentration and centralisation even in the absence of government regulation. In an uncertain environment promises to pay are inevitably of different quality, and the process of acquiring a good reputation in this respect will have a self-reinforcing quality. It is easy to see how a hierarchy can develop in which promises to pay by less reputable individuals or institutions will only be acceptable if guaranteed or backed in some way by those of more reputable issuers. Thus, there are cogent reasons to believe that pressures for the concentration and 'pyramiding' of reserves will arise even in the absence of government legislation favouring a particular institution (Goodhart, 1988, Dow and Smithin, 1992), and it is difficult to imagine how power relationships can be excluded from such an environment.

The virtue of the evolutionary-type theories of the development of monetary institutions is precisely that they emphasise the point that the ultimate determinants of what qualifies as 'money' are the demand-side factors of trust and confidence, and that these qualities are self-reinforcing. Even in the Mengerian theory, for example, where no government is present, the reason that a 
precious metal becomes the most saleable commodity is simply that transactors will always be prepared to accept this commodity because they have confidence that others will later do the same. It was always recognised that the actual use values of the precious metals concerned were rather limited.

If the demand-side factors really do predominate, the analyst is obviously not entitled to rule out any particular candidate for the role of the ultimate monetary asset. Nonetheless, if the hypothesised system is thought of as evolving from contemporary conditions, as opposed to emerging de novo with no previous history, it seems more plausible that the final repository of purchasing power in the absence of government would come to be a uniquely trustworthy financial asset such as the liabilities of some long-established and commercially successful financial institution. As with the liabilities of contemporary central banks, these may originally have been promises to pay some pre-existing final redemption medium, but eventually they come to be acceptable in and of themselves as representing ultimate payment. They will, of course, be backed by the institution's asset portfolio, which by hypothesis is regarded as particularly solid, but a point is reached at which there is no danger of any creditor actually requiring payment in some subset of the bundle of real assets underlying the portfolio.

In modern conditions, therefore, Wicksell's originally fanciful notion of the 'pure credit economy' would seem to be as viable a monetary system as ancient commodity money standards or contemporary fiat money systems, all of which rest or rested on no firmer foundation than a convention (sometimes reinforced with legal restrictions) as to what should represent the ultimate means of payment. It has indeed been suggested that the contemporary laissez-faire theories are themselves ultimately descended from Wicksellian ideas. But there is a crucial difference that, in Wicksell, changes in the money rate of interest (and hence monetary policy in that sense) do have an important impact at least on the inflation rate. This would not be the case in the more contemporary theories. Hicks $(1982,1989)$ and Smithin (1994), for example, would go further than Wicksell in allowing interest rate changes to have a real as well as inflationary impact.

In a credit economy, the only method of discharging the payments function is by an exchange of debts (Hicks, 1982, 1989), and when, for example, a retailer accepts from a consumer 
a cheque drawn on a financial intermediary, the retailer is simply exchanging the debt of the consumer for the debt of the financial intermediary. From the point of view of the retailer this is a workable arrangement as long as there is a third party who will, in turn, be prepared to accept those promises to pay in exchange for goods and services. However, given the difficulty of evaluating promises to pay, there will be a tendency for the retailer to regard those of a recognisable financial intermediary as more reliable that those of an isolated individual; the retailer would only accept claims against some peripheral institution if backed by claims against a more reputable concern, and so on down the line. At the centre of the system will be either a single institution, or perhaps a small group of institutions, whose promises to pay have come to regarded as more reliable and hence more widely acceptable than those of the others.

Within a limited arena such as the national economy of a small or medium-sized jurisdiction, it may well be the case, as a practical matter, that only one central player emerges. At the level of pure theory, however, and absent government intervention, there is no need to identify the concept of a monetary network with national political boundaries. Depending on historical circumstances, these boundaries may occupy either a larger or smaller area. We can easily imagine situations where there are two or more players who have developed their own spheres of financial influence (which may overlap geographically) and which monopolistically compete. In this case, issues of exchange rate determination and interest parity would begin to arise.

When, within a given financial network, at a certain stage the liabilities of the central institution are in practice no longer redeemable into anything else, we can imagine the value of the abstract unit of account being influenced by the portfolio choices of that institution in much the same way that the choices of central banks influence the value of the medium and unit of account today. The important difference between this type of process and systems based on 'hard money', however, is that when the redemption medium is a financial asset rather than a physical asset, supplies of the medium can be readily increased simply by the central institution standing ready to make loans denominated in those terms. Monetary policy reduces to the setting of interest rates by the central institution (Hicks, 1982; Moore, 1988), which provides the incentive or otherwise for other agents in the economy to take credit denominated in terms of its own liabilities. 
Much of this discussion is of course hypothetical. Even if laissez-faire in the financial services sector did exist in most respects, in practice it must be expected that the existing central banks (or new supra-national central banks as in current EU proposals) would continue to occupy the commanding heights of most monetary systems. This situation would persist unless central banks are abolished outright and such legislation as legal tender laws repealed. Similarly, the central bank (or banks) of the most commercially successful nations would dominate the world stage. There would be little purpose in calling for the abolition of state central banks, as do members of all the laissez-faire schools discussed above, if in any event the market is likely to throw up similarly powerful private sector institutions, which would then be responsible de facto for the monetary policy of the system. These institutions would presumably either have to 'socialise themselves', as Keynes (1926; 1972) claimed was the case with the Bank of England historically, or else be subjected to government regulation of some kind in response to the public interest arguments which would inevitably be made.

\section{PUBLIC GOODS AND NATURAL MONOPOLIES}

The case being made here for central banking, or, more generally, some governmental role in the provision of monetary services, differs from the conventional argument, that there are significant public good or natural monopoly elements in the provision of such services. Laidler (1990a) has recently re-stated this view as did Friedman (1960) thirty years earlier in an oft-cited passage. Adherents of the MFB school, however (White, 1989, Dowd, 1993) claim to refute both defences of central banking. It is argued, for example, that money fails to satisfy either the non-rivalry-inconsumption or non-excludability criteria to qualify as a public good. Social or 'network' externalities in the use of money are admitted, in the sense that a given money, like a language or a telephone system, is more useful the greater the number of transactors who are prepared to accept it. In the Mengerian tradition, this property is actually used to explain why there will tend to be convergence to a common monetary standard. The point seems to be missed that this will inevitably confer an element of power on whoever can control or 'corner the market' in the asset or commodity which comes to define the standard. Moreover, as Dow (1993, forthcoming) argues, it is the attribute of 
'moneyness', rather than any particular monetary asset, whih exhibits public good characteristics. It is certainly true that, under certain conditions, the private sector can generate conventions equivalent to public interest regulation, via the pursuit of agent self-interest. But his observation in itself does not preclude a legitimate debate over the appropriate extent of public versus private involvement.

Melvin (1988) has made the case for natural monopoly in terms of the high fixed costs for financial institutions of building 'confidence capital' in their liabilities (such as the construction of imposing buildings, hiring competent staff, or, in a reserve-based system, the costs of holding reserves) as compared with the low marginal costs of producing additional money balances. Klein (1974) has also suggested that there are natural monopoly elements in monetary systems, while arguing nonetheless that this does not provide grounds for state intervention. The MFB school would go further in denying the existence of such economies of scale in money production (White, 1989, Dowd, 1993) on both theoretical and empirical grounds. It is argued, for example, that the costs of maintaining confidence are not fixed but rise with the quantity of real balances to be kept in circulation, that the quantitative magnitude of economies of scale in reserve-holding are trivial, and/or that empirical studies have shown that production-based economies of scale in the provision of financial services are exhausted at relatively small plant sizes.

Our view, however, is that whatever the outcome of the debate about 'technical' productionbased economies of scale, this is actually of very little relevance to the genuine demand-side arguments for the existence of centralising tendencies in monetary and financial systems. In the case of money it is highly doubtful whether the natural monopoly element should be deduced solely by analogies to physical production processes. The point is surely rather that the nebulous factors of 'confidence' and 'trust' are attributes assigned to different monetary assets by the opinions of those who hold them. It seems unlikely, in fact, that there will be any determinate relationship between the volume of expenditure on imposing buildings or glossy brochures and the formation of 'confidence capital', or indeed that there is any set of relationships which could be identified as a stable 'production function'. The process is much less deterministic than these concepts imply, conditioned in practice by all sorts of historical accidents and situation-specific factors, and the conventions these generate. Dowd (1989) points to the transactions costs entailed in changing unit- 
of-account conventions. But the importance of conventions within financial markets has more general relevance. It is the demand-side characteristics of the competing promises to pay which are all-important. The institution which has established a solid reputation in the past, through successful performance or historical circumstance, may well continue to be able to exercise some degree of market power precisely because of that fact. This can continue as long as there is no overt reason for market participants to change their minds. In the words of Walter Bagehot (1873; 1915):

'An old established bank has a "prestige", which amounts to a "privileged opportunity"; though no exclusive right is given to it by law, a peculiar power is given to it by opinion.....The business of an old-established bank has the full advantage of being a simple business, and in part the advantage of being a monopoly business.'

\section{EMPIRICAL EVIDENCE}

Marshalling concrete empirical evidence for or against the competing propositions under discussion here is not straightforward, despite the recent explosion of interest in historical episodes of free banking (e.g., Capie and Woods, 1991). However, as the recent debates have illustrated, the historical evidence may never be sufficiently clearcut to provide decisive affirmation or rebuttal. For example, the history of the Bank of England is certainly an instance of a situation in which a legally

private commercial firm did rise to dominate the financial system of an entire country (and eventually the world) and whose liabilities became the de facto reserve of the system in spite of nominal adherence to a gold standard (Bagehot, 1873; 1915, Hicks, 1986). However, both the adherents of both the MFB and NME-LRT schools would point to this as precisely the pre-eminent example of a distorted system created by the accumulation of legislative privileges for this single firm (Dowd, 1991).

Some writers have noted historical cases in which market forces apparently led to the emergence of hierarchical systems of control in private-sector financial networks even in the absence of legislation. For example, Goodhart (1988) points to the development of the Suffolk System in early nineteenth century New England as a prime example of something akin to a private central 
banking system arising spontaneously as a result of market forces. He also refers to the position of the New York City banks later in the century (in the National Banking era) when six or seven banks held three-quarters of interbank deposits. Mullineaux $(1987,1988)$ and Gorton and Mullineaux (1987) have also studied the experience of the Suffolk system and the later commercial bank clearing house $(\mathrm{CBCH})$ systems in the nineteenth-century USA, with emphasis on arrangements for the joint production of 'confidence', and in the case of the Suffolk system the resemblance of such systems to franchise contracts.

Although Selgin and White (1987) assert that 'none of the (other) relevant historical cases shows any tendency towards significant interbank deposits', other writers have noticed tendencies towards centralization even in those cases (Scotland, Canada and Sweden). In both Scotland and Canada, the reliance of the domestic banking systems on London and New York respectively has been remarked by writers such as Goodhart (1987), Rothbard (1987), Sechrest (1988), and Cowen and Kroszner (1989). Also, in the case of Scotland, Checkland (1975), Munn (1981), Gorton (1985) and Dow and Smithin (1992) have pointed to the quasi-central banking role of the three public banks.

A common problem with attempts to draw definite conclusions from the historical literature is that there is no really clearcut factual example of free banking which is not 'contaminated' in some form by at least a rudimentary legislative framework which may be held to distort the system in one way or another. Nevertheless, such evidence as exists is highly suggestive; even in cases, such as Scotland, which were as 'free' as could reasonably be expected to occur in practice, the centralisation tendencies are evident (Dow and Smithin, 1992), although it will always be possible to object that this result is dependent on whatever residual legal restrictions can be found in the system. If an appeal to the historical record is not decisive, the prospects are not much better for a decisive empirical test for the futurist 'thought experiments' which various authors have conducted. It is admitted that, from the point of view of practical politics, the chances of actual implementation of these schemes are not high (Selgin and White, 1994).

In the face of all these difficulties, we would argue that the most straightforward demonstration of the tendency towards the concentration of financial power is actually to be found 
in the international sphere, in the phenomenon of the emergence of international reserve currencies and the apparent domination of the international financial system at different periods by the central bank of the most economically powerful nation of the day. The role of the Bank of England and the pound sterling internationally during the 19th century would be the prototype of this situation. As Hicks (1986) has remarked the international monetary system of that era was not so much a gold standard as a sterling standard, with London 'acting as a sort of central bank for the whole world economy'. In more recent times, the obvious examples would be the international role of the US dollar both during the Bretton Woods era and even afterwards down to about the mid-1980s, and the dominant role of the German Bundesbank and the D-mark within the European Monetary System (EMS) in the 1979-93 period. The process by which a national currency becomes an international reserve currency is clearly independent of any legal restrictions imposed at the national level. Even when such arrangements are formalised in an international agreement or treaty (as in the case of Bretton Woods) these could not be binding, in the absence of an effective international legal system and enforcement mechanism, unless there are genuine economic and/or political reasons for the arrangements to persist. The fact that the US dollar, for example, continued to function as an international reserve currency in the 1970s even after the Bretton Woods system had broken up, is a clear illustration of this point.

In fact, the identity of the international reserve currency at any given time seems to be based on the most crude indicators of national economic success, such as a large creditor position against other nations. As in the case of the nineteenth century UK, these credits may actually be denominated in the currency of the reserve centre itself, but they ultimately represent a claim against the real resources of other nations built up by superior economic performance over time. Any promises to pay issued on the security of that creditor position become more trustworthy than those of any rival and will themselves be regarded by third parties as adequate payment for goods and services received. In the case of the UK, the move from creditor to debtor status after World War I could then account for its demise as the world financial centre; a similar could be made of recent changes in the relative status of the US dollar, yen and D-mark. But, even if the identities of the financial superpowers change over time by some Schumpeterian process, the main point is that it is 
basic economic forces (albeit at the international level) which are driving the changes, elevating one centre and diminishing another. There is no world government favouring one centre over another by binding legislation. Moreover, those forces seem clearly to lead towards a high degree of centralisation of the system and not to the international equivalent of free banking. This appears to be the clinching argument, at least as far as an appeal to the historical evidence can take us.

\section{CONCLUSION}

Of the various approaches to the reconstruction of monetary theory outlined above, it has been argued here that the approach which emphasises credit relations represents the best way to cut through the confusion surrounding the role of money in the contemporary market economy. This approach recognises that the majority of market transactions occurring in real time do have the basic characteristic of an exchange of debts, and that completion of the monetary side of the transaction implies a repayment of debt. The economic system therefore rests in an essential way on the need to establish trust and confidence in an uncertain environment, and this in turn, in any given system, requires the development of a basic monetary asset both to fix the standard of value and unambiguously represent final payment.

As is obvious from current practice, multiple exchange media other than the final medium of redemption can arise, but by definition they will attract less confidence and must be related to the ultimate means of payment in some way, such as by redemption pledges. The notorious fragility of credit systems arises, in situations when the reliability of some or all of the substitute exchange media has come into question for some reason.

Experience with contemporary systems, in which the ultimate reserve asset consists simply of the nominal liabilities of state central banks shows that it is not necessary for the central asset to be 'hard money' such as gold or another precious metal. All that is required for an asset to be accepted as final payment of a debt is confidence that others will also accept it as such in some subsequent round of transactions. The obligations of the state do fulfil this requirement under most circumstances (with some obvious exceptions) which is why central bank liabilities will usually be accepted as final payment. It may also be observed that the only reason why gold was regarded as 
final payment in the past was similarly an underlying confidence that it would be equally acceptable to others.

It is clear, nonetheless, that monetary systems in which the ultimate reserve asset is not in fixed supply will operate in a different fashion from those in which it is. In the former, supplies of the reserve asset can readily be increased whenever the issuing institution is willing to make loans. The interest rate on those loans, rather than any quantity principle, then becomes the main instrument by which the reserve asset can be rationed. An implication is that some free banking reform porposals could turn out to be actively damaging if they blocked the development of a reserve asset with the appropriate degree of endogeneity, thus increasing, rather than reducing, the potential for instability.

Attempts to ground an explanation of money solely in the need to reduce the inefficiency of barter in a static exchange economy do not go far enough. The design of hypothetical alternative systems to replace static barter is, in a sense, too easy a task, immediately opening up the possibility that 'money' can be replaced by a sophisticated accounting system of exchange as soon as the technology permits. As against this, it might be argued that there is no technology which can eliminate the uncertainty inherent in production and exchange decision-making in the market economy in real time. In particular, continued activity in such an economy implies a need to judge the quality of individual promises to pay on an ongoing basis. This is what ultimately determines the need for a basic monetary asset embodying both the standard of value and representing the ultimate means of payment. Changes in technology may well change the form which this asset takes, but do not eliminate the need for it. 


\section{ENDNOTES}

1. However, see McKinnon and Smithin (1993) for an attempt in this direction.

2. Hodgson (1992) has recently offered a number of additional criticisms of the Mengerian-type theory, both as an excercise in evolutionary economics and as a defence for laissez-faire in the provision of monetary services.

3. This evidently puts forward a very different view of money from that of the same author's early contributions (Hicks, 1935, 1937).

4. This in itself may raise some questions as to the political feasibility of most free banking proposals. 


\section{REFERENCES}

Bagehot, W. (1873; 1915). Lombard Street. London: John Murray.

Black, F. (1970). Banking and interest rates in a world without money. Journal of Bank Research, vol.1, pp.9-20.

Buchanan, J.M. and Fand, D.I. (1993). Monetary malpractice: intent, impotence or incompetence?. Critical Review, vol. 6, no.4, pp.457-69.

Capie, F. and G. Wood, eds., (1991). Unregulated Banking: Chaos or Order?. New York: St. Martin's Press.

Checkland, S.G. (1975). Scottish Banking: A History. Glasgow: Collins.

Chick, V. (1986).'The evolution of the banking system and the theory of saving, investment and interest. Economies et Societies, vol.20, pp.111-26. Reprinted in On Money, Method and Keynes: Selected Essays of Victoria Chick (ed. P. Arestis and S.C. Dow). London: Macmillan, 1992.

Cowen, T. and Kroszner, R. (1987).'The development of the new monetary economics. Journal of Political Economy, vol.95, pp.576-90.

(1989).'Scottish banking before 1845: a model for laissez-faire?. Journal of Money,

Credit,and Banking; vol.21, pp.221-31.

(1994). Explorations in the New Monetary Economics. Oxford: Basil Blackwell.

Davidson, P.A. (1978). Money and the Real World (second edition). London: Macmillan.

Dow, S.C. (1993). Money and the Economic Process. Aldershot: Elgar.

(forthcoming).'Why the financial system should be regulated, Economic Journal.

Dow, S.C. and Smithin, J.N. (1992). Free banking in Scotland, 1695-1845. Scottish Journal of Political Economy, vol.39 (November), pp.374-90.

Dowd, K. (1989). The State and the Monetary System. Hemel Hempstead: Philip Allan.

--- (1991). The evolution of central banking in England, 1821-90. In Unregulated Banking:

Chaos or Order (ed. Forest Capie and Geoffrey E. Wood). New York: St. Martin's Press, pp.159-95. 
---- (1992) The Experience of Free Banking: London: Routledge.

-_.-(1993). Laissez-Faire Banking: London and New York: Routledge.

---- (forthcoming). The case for financial laissez-faire. Economic Journal,.

Eichengreen, B. (1993). European monetary unification. Journal of Economic Literature, vol.31 (September), pp.1321-57.

Fama, E.F. (1980). Banking in the theory of finance. Journal of Monetary Economics, vol.6, pp.39- 57.

(1983). Financial intermediation and price level control. Journal of Monetary Economics, vol.12, pp.7-28.

Friedman, M. (1960). A Program for Monetary Stability. New York: Fordham University Press.

Glasner, D. (1989). Free Banking and Monetary Reform. Cambridge: Cambridge University Press.

Goodhart, C.A.E. (1988). The Evolution of Central Banks. Cambridge, Mass: MIT Press.

Gorton, G. (1985). Banking theory and free banking history: a review essay. Journal of Monetary

Economics, vol.16, pp.267-76.

--a-- and D.J. Mullineaux (1987). The joint production of confidence: endogenous regulation and nineteenth-century commercial bank clearing houses. Journal of Money, Credit, and Banking, vol.19, pp.457-68.

Greenfield, R.L. and Yeager, L.B. (1983).'A laissez-faire approach to monetary stability. Journal of Money, Credit, and Banking, vol.15, pp.302-15.

(1989). Can monetary disequilibrium be eliminated?. Cato Journal, vol.9, pp.405-21.

Hahn, F. (1983). Money and Inflation. Cambridge, MA: MIT Press.

Hall, R.E. (1982a). Explorations in the gold standard and related policies for stabilizing the dollar. In Inflation: Causes and Effects, Chicago: University of Chicago Press.

(1982b). Monetary trends in the United States and the United Kingdom: a review from the perspective of new developments in monetary economics. Journal of Economic Literature, vol.20, pp.1552-6.

Hayek, F.A. (1976; 1978). Denationalization of Money - The Argument Refined. London: IEA.

Hicks, J.R. (1935). A suggestion for simplifying the theory of money. Economica, vol.2, pp.1-19. 
(1937). Mr. Keynes and the classics. Econometrica, vol.5, pp.147-59.

- (1967). Monetary theory and history: an attempt at perspective. In Critical Essays in

Monetary Theory. Oxford: Clarendon Press.

-1982).'The credit economy. In Money, Interest and Wages: Collected Essays on Economic Theory, vol.2. Oxford: Basil Blackwell.

-.-. (1986). Managing without money. In Chung-Hua Series of Lectures by Invited Eminent

Economists, 11. Tapei: Academia Sinica.

--.-(1989). A Market Theory of Money. Oxford: Oxford University Press.

Hodgson, G.M. (1992). Carl Menger's theory of the evolution of money: some problems. Review of Political Economy, vol.4, no.4, pp.396-412.

Hoover, K.D. (1988). The New Classical Macroeconomics: A Sceptical Inquiry. Oxford: Basil Blackwell.

Kaldor, N. (1970). The new monetarism, Lloyds Bank Review, July, pp.1-18.

-1986). The Scourge of Monetarism (second edition). Oxford: Oxford University Press.

Keynes, J.M. (1926; 1972). The end of laissez-faire. Reprinted in Collected Writings, vol. IX, Essays in Persuasion (ed. D. Moggridge). London: Macmillan.

Klein, B. (1974). The competitive supply of money. Journal of Money, Credit, and Banking, vol.6, pp.423-53.

Laidler, D.E.W. (1990a). Taking Money Seriously and Other Essays. London: Philip Allan.

-.-.- (1990b). Hicks and the classics: a review essay. Journal of Monetary Economics, vol.25, pp.481-9.

Lavoie, M. (1984). The endogenous flow of credit and the Post Keynesian theory of money. Journal of Economic Issues, vol.18, pp.771-96.

McCallum, B.T. (1985). Bank deregulation, accounting systems of exchange and the unit of account: a critical review. Carnegie -Rochester Conference Series on Public Policy, vol.23, pp.13 -46.

McKinnon, K.T. and Smithin, J. (1993). An interest rate peg, inflaion and output. Journal of Macroeconomics, vol.15, no.4 (Fall), pp.769-85.

Melvin, M. (1988). Monetary confidence, privately produced monies, and domestic and international 
monetary reform. In Political Business Cycles: The Political Economy of Money, Inflation and Unemployment (ed. T.D. Willet). Durham, NC: Duke University Press.

Menger, C. (1892). On the origin of money. Economic Journal, vol.2, pp.239-55.

Minsky, H. (1978). The financial instability hypothesis: a restatement. Thames Papers on Political Economy, utumn.

-.--(1986). Stabilizing an Unstable Economy. New Haven: Yale University Press.

Moore, B.J. (1988). Horizontalists and Verticalists: The Macroeconomics of Credit Money. Cambridge:

Cambridge University Press.

Mullineaux, D.J. (1987). Competitive monies and the Suffolk Bank system: a contractual perspective. Southern Economic Journal, vol.53 (April) pp.884-98.

(1988). Competitive monies and the Suffolk bank system: reply. Southern Economic Journal, vol.55 (July), pp.220-23.

Munn, C.W. (1981). The Scottish Provincial Banking Companies, 1747-1864. Edinburgh: John Donald.

Rogers, C. (1989). Money, Interest and Capital: A Study in the Foundations of Monetary Theory. Cambridge: Cambridge University Press.

Sechrest, L.J. (1993). Free Banking: Theory, History, and a Laissez-Faire Model. Westport, Connecticut: Quorum Books.

Selgin, G.A. (1988). The Theory of Free Banking. Totawa, NJ: Rowan \& Littlefield. and White, L.H. (1987). The evolution of a free banking system. Economic Inquiry, vol.25, pp.439-458.

(1994). How would the invisible hand handle money? Journal of Economic Literature, vol.32 (December), pp.1718-49.

Shackle, G.L.S. (1974). Keynesian Kaleidics. Edinburgh: Edinburgh Univeristy Press.

Smith, V.C. (1936; 1990). The Rationale of Central Banking and the Free Banking Alternative. Indianapolis: Liberty Press.

Smithin, J.N. (1994). Controversies in Monetary Economics: Ideas, Issues and Policy. Aldershot: Edward Elgar. 
Trautwein, H-M. (1993). A fundamental controversy about money: Post Keynesian and New Monetary Economics. In Macroeconomic Theory: Diversity and Convergence (ed. G. Mongiovi and C. Ruhl), Aldershot: Edward Elgar.

Wallace, N. (1983). A legal restrictions theory of the demand for money and the role of monetary policy. Federal Reserve Bank of Minneapolis Quarterly Review, Winter, pp.1-7.

(1988). A suggestion for over simplifying the theory of money' Economic Journal vol.98 (Supplement), pp.25 -36.

White, L.H. (1984a). Free Banking in Britain: Theory, Experience, and Debate, 1800-1845. Cambridge: Cambridge University Press.

---- (1984b). Competitive payments systems and the unit of account. American Economic Review, vol.74, pp.699-712.

-.-.- (1987). Accounting for non-interest-bearing currency: a critique of the legal restrictions theory of money. Journal of Money, Credit, and Banking, vol.19, pp.448 -56.

--a-- (1989). Competition and Currency: Essays on Free Banking and Money. New York: New York University Press.

Willet, T.D. (1988). Political Business Cycles: The Political Economy of Money, Inflation and Unemployment. Durham, NC: Duke University Press

Wray, L.R. (1990). Money and Credit in Capitalist Economies: The Endogenous Money Approach. Aldershot: Edward Elgar. 
